\title{
A EFETIVIDADE DOS DIREITOS FUNDAMENTAIS INDIVIDUAIS E SOCIAIS E A ESPERANÇA NA JUSTIÇA BRASILEIRA
}

José Renato Nalini ${ }^{1}$

Marcelo Gonçalves da Silva ${ }^{2}$

\section{Resumo}

A presente temática: "efetividade de direitos fundamentais e esperança na justiça" se justifica ante o precário quadro político e socioeconômico brasileiro. Política e economia se distanciaram sobremaneira dos valores constitucionais e sociais. A atualidade mostra que as normas constitucionais estão relegadas a um papel meramente simbólico, razão pela qual se exige do Poder Judiciário uma postura mais dinâmica e voltada ao atendimento dos interesses da sociedade. O corte epistemológico se dá por uma análise das múltiplas causas e efeitos da deficiência da máquina judiciária, instante em que emerge a problemática se é possível ter esperança de Justiça face aos desmandos, morosidade e ineficiência do Estado. Destarte, utilizando-se uma metodologia dedutiva e crítica da realidade, tendo como marco teórico inovadoras teorias jurídicas, apresentar-se-á uma hipótese que responda aos problemas identificados, trazendo esperança ao jurisdicionado e restabelecendo sua confiança no Poder Público e sua eficiência. Objetiva-se mostrar as lacunas do sistema e apontar que o Judiciário é o acesso mais seguro no momento.

Palavras-chave: Direitos Fundamentais. Eficiência. Poder Judiciário.

\section{INTRODUÇÃO}

1 Doutorado pela Universidade de São Paulo - Usp. Professor de Direito do Mestrado da Universidade Nove de Julho/Sp. E-mail: jose-nalini@uol.com.br

2 Mestrando em Direito, ambos pela Universidade Nove de Julho/sp. E-mail: marcelo.advpaulista@gmail.com 
Pretende-se fazer uma análise da efetividade dos direitos fundamentais e sociais, os quais são essenciais à realização da natureza humana, bem como reestruturação da sociedade nos moldes sustentáveis.

Devido à retração dos outros poderes, o Poder Judiciário assumiu maior destaque no cenário nacional, sendo ainda mais importante na democratização e construção de um Estado mais humano, justo, ético e solidário.

Ocorre que existe um conjunto de causas, as quais formam o esteio que corrói a eficiência e hombridade do Judiciário brasileiro, deixando ao cidadão a dúvida se é possível ainda acreditar na justiça, não enquanto conceito filosófico e abstrato, mas num valor intimamente ligado à realidade concreta.

Essas concausas perpassam o âmbito político, econômico, cultural e administrativo, influindo diretamente no funcionamento estrutural da máquina judiciária. Considerando que o Judiciário é o mais próximo poder da sociedade, nele são depositadas as últimas esperanças de restauração da vida social e de uma existência digna.

De igual modo, o Judiciário tem além de suas competências constitucionais, legitimidade e respeitabilidade, o poder de concretizar o projeto de desenvolvimento do Estado brasileiro, pela aplicação prática da norma constitucional, sejam as preceituais ou axiológicas.

Destarte, o magistrado em seu âmbito de atuação, se munido de uma consciência ética, justa, humana e de ousadia perante a Constituição e a situação social atual, pode contribuir para diminuir substancialmente o sofrimento e descrédito da população nas entidades públicas.

Por meio de uma metodologia dedutiva e crítica da realidade, ao arrepio de importante marco teórico lastreado na obra "Justiça e o Paradigma da Eficiência", cujo conjunto de renomados autores, conta com o Dr. José Renato Nalini que por seu portentoso conhecimento e larga experiência à frente do Tribunal de Justiça de São Paulo, contribui consideravelmente para o diagnóstico e solução do problema levantado.

Assim, apontando a relação de causa e efeito, e identificando-se os elementos nocivos que atravancam o Judiciário, este trabalho pretende apresentar uma hipótese ressignificante da justiça, haja vista a importância dos direitos fundamentais no desenvolvimento da pessoa humana e da sociedade em seu conjunto.

Tendo em vista que o problema do déficit judiciário é multifatorial, logicamente a solução proposta engloba um composto de medidas, o qual se acredita poder construir uma máquina judiciária eficiente e capaz de resgatar a confiança do cidadão comum, que desacreditado pelo não cumprimento das promessas políticas, tem na promessa jurídica, talvez, a única esperança.

Assim, considerando a atual conjuntura política, econômica e social do Brasil, é importantíssimo falar das deficiências do Judiciário e ao mesmo tempo de sua potencialidade, haja vista que se tornou a "tábua de salvação" 
daqueles que são explorados por um sistema capitalista voraz, e rejeitados por uma política elitista e votada apenas à satisfação de interesses pessoais.

Portanto, o Poder Judiciário, sustentáculo do Estado democrático, por meio de seus membros têm a nobre missão de resgatar a dignidade humana aplicando os direitos constitucionais e subtraindo da Carta Maga seu caráter meramente simbólico, atribuindo-lhe a efetividade esperada.

\section{GENESE DO PROBLEMA POLITTICO E ECONÔMICO BRASILEIRO}

A despeito de o Brasil ser uma das maiores economias mundiais, todavia, esse fator não reflete no nível do desenvolvimento humano, haja vista o país ocupar atualmente a 79a posição no IDH, segundo relatório da Organização das Nações Unidas (ONU) produzido em 2016.3

Essa discrepância pode ser vista na falta de infraestrutura e na precariedade dos serviços públicos prestados à população, tais como saúde, salário, educação, moradia, dentre outros.

Inobstante, o país demonstrar uma alta capacidade na produção de ativos (bens serviços), essa riqueza não é distribuída de maneira justa e igualitária entre todos os atores sociais que dela participam.

Nesse aspecto há que se diferenciar entre crescimento e desenvolvimento, haja vista que o primeiro termo liga-se mais à economia, ao passo que o segundo tem um maior acento jurídico.

O crescimento econômico está ligado à capacidade que o país possui em administrar sua matriz geradora de riquezas, através dos investimentos na indústria, comércio e prestação de serviços, os quais fomentam a economia, geram novas tecnologias, criam empregos e atraem divisas para o país.

A seu turno, o desenvolvimento, embora evidentemente ligado à economia, possui uma conotação mais jurídica, pois tem a ver com a competência que o país tem em distribuir a riqueza gerada de modo a elevar a qualidade de vida de seus cidadãos.

Nesse passo, o desenvolvimento tem a ver com a excelência da prestatividade dos serviços públicos, com o desenvolvimento e realização do potencial humano, conectando-se a uma vida qualitativa, com senso de felicidade, lazer, trabalho digno e bem remunerado e respeito ao meio ambiente natural.

Portanto, crescimento e desenvolvimento não se confundem. Assim, é enganoso quando se divulga o desenvolvimento do país apenas com lastro nos números do Produto Interno Bruto (PIB), usando-se o indicador de renda "per capita", como principal referencial, pois:

3 Disponível: <https://gl.globo.com/.../em-79-lugar-brasil-estaciona-no-ranking-de-desenvolvimento...> Acessado em 20 de nov. de 2017). 
[...] é um indicador da evolução do padrão e da capacidade de produção de ativos de um país e, em função da sua comodidade explanatória, tem sido amplamente utilizado como fato de caracterização do desenvolvimento. [...] Esse modelo (renda per capita), contudo, ao produzir a média comparativa, nada diz a respeito do modo como essa riqueza está distribuída, porque a sua estrutura matemática oculta a questão central de que a riqueza geral não está distribuída de forma igualitária, e isto distorce o resultado-padrão de forma significativa. (SILVEIRA; SANCHES \& COUTO, 2013, p. 38) (grifo nosso).

O desenvolvimento é uma dos objetivos fundamentais do Estado brasileiro, o qual se hospeda no artigo 3o, inciso II, da Carta Política atual, razão pela qual sua efetivação depende de uma ação direta e enérgica do Poder Público.

Destarte, tanto o crescimento econômico, garantido por uma economia forte, quanto o desenvolvimento, respaldado por uma atuação efetiva do Estado, são itens de suma importância para a realização dos direitos fundamentais individuais e sociais.

Isso porque, apenas com recursos materiais abundantes se torna possível a realização dos direitos fundamentais previstos na Constituição Federal. Boas escolas, hospitais, moradias, alimentação, profissionalização, lazer, segurança, e outros, dependem de recursos econômicos e financeiros.

O Brasil adotou o sistema econômico capitalista, conforme se depreende da leitura dos artigos $1^{\circ}$, IV e170, em que são elencados princípios básicos desse sistema, tais como trabalho, livre-iniciativa, livre concorrência e propriedade privada. Assim:

No caso do Brasil, o modo de produção desenvolvido é o modo de produção capitalista, explicitado e garantido pela Constituição Federal ao proteger e defender em seus princípios fundamentais os elementos que o compõem. A economia de mercado é garantida constitucionalmente, pois seus elementos fundamentais estão resguardados na Constituição Federal - livre iniciativa, trabalho assalariado (art. 10, IV) (DERANI, 2008, p. 8).

Ocorre que o modo de produção capitalista é extremamente racional, técnico e voltado quase que exclusivamente à busca do lucro. Este, em si mesmo não é imoral ou ilegal, constitui-se na própria essência da economia de mercado.

Entretanto, o lucro não deve ser o único propósito de uma empresa, haja vista que ela se instala na sociedade, dela retirando todas as condições naturais, artificiais e humanas para seu crescimento.

Destarte, a empresa deve ser vista como um organismo social que devolve à sociedade parte dos lucros que percebe, por meio de investimentos sociais na própria comunidade em que se encontra instalada:

A empresa é vista como um sistema em que se desenvolvem diversas atividades que extrapolam o âmbito econômico. Torna-se personagem direto do desenvolvimento social, e deve, portanto, atuar nesse papel como um instrumento de concretização dos direitos humanos e de melhoria na qualidade de vida das pessoas, sem se descuidar da preservação dos recursos naturais (SILVEIRA, et al., 2013, p. 18).

No Brasil, porém, essa realidade ainda é distante, pois o capitalismo atuante no país é extremamente concentrador da riqueza, individualizando o lucro e gerando graves mazelas sociais, como fome, miséria, 
desemprego, violência, etc.

A despeito de a Constituição Federal atribuir contornos humanos e sociais ao capitalismo, o vetor hermenêutico da dignidade da pessoa humana e a função social da propriedade, verdade é que se não houver uma intervenção efetiva do Estado na economia, dificilmente os direitos fundamentais irão se concretizar.

Já foi demonstrado pela história que as premissas dogmáticas do liberalismo são falaciosas, pois deixar a ordem econômica à própria sorte, afastando a atuação estatal, seria como "entregar á raposa, a chave do galinheiro".

Desse modo, o Estado torna-se o personagem central, responsável por resolver os conflitos entre as classes sociais, consertar os efeitos colaterais produzidos pelo sistema capitalista, e alavancar o desenvolvimento sustentável:

O desenvolvimento é condição necessária para a realização do bem-estar social. O Estado é, através do planejamento, o principal promotor do desenvolvimento. Para desempenhar a função de condutor do desenvolvimento, o Estado deve ter autonomia frente aos grupos sociais, ampliar suas funçōes e readequar seus órgãos e estrutura (BERCOVICI, 2005, p. 51).

O liberalismo econômico pressupõe omissão estatal no domínio econômico sob o argumento de que o mercado se autorregula. Ocorre que tal premissa desconsidera que o mercado é organizado e dirigido por mentes humanas.

Por conseguinte, o mercado econômico possui um perfil psicológico e uma lógica intrínseca aos seus próprios objetivos, qual seja, a acumulação da riqueza. $\mathrm{O}$ afastamento do Estado implica na própria desordem do mercado, e no prejuízo aos interesses coletivos. Tal fato é mostrado na própria passagem do capitalismo de concorrência para o capitalismo de monopólio:

[...] é importante chamar a atenção para o seguinte fato: numa fase da história em que se atinge tão alta concentração de poder econômico como no caso do capitalismo de monopólio, a máquina do Estado torna-se um instrumento dos grupos monopolistas dominantes. O monopólio, visto implicar uma concentração de poder dentro do sistema capitalista, resulta num controle político muito mais forte e estreito sobre a sociedade e a política do governo (CATANI, 1984, p. 73).

A omissão estatal significa sucumbência ante a economia de mercado, razão pela qual a concepção liberalista torna-se ideologia, pois desvirtua o Estado de sua missão principal de realizar o bem comum, tende a acirrar as tensões entre os diferentes atores sociais, bem como neutraliza o poder efetivo da Constituição Federal:

O Estado age a fim de melhor organizar a produção e para neutralizar tensões inerentes ao processo produtivo, entre o que seja público e privado, entre democracia e capitalismo, conforme já diagnosticou Habermas. [...] A perseguição da realização do bem comum pelo Estado afasta a concepção liberal de lei, que se pautava numa igualdade fictícia, e dirige-se para uma atividade em busca de concreta justiça distributiva (DERANI, 2008, pp.9-10).

Nota-se que, face às constantes crises enfrentadas pelo Estado brasileiro, e, tendo em vista a caótica realidade socioeconômica do país, percebe-se que o agente político encarregado de organizar e promover o 
desenvolvimento nacional, tem perdido forças ante os atores econômicos.

Por causa da retração política, até mesmo o direito se enfraquece, haja vista que esses dois campos científicos e pragmáticos estão intimamente ligados. As recentes reformas da previdência e do trabalho revelaram supressão de direitos e infligiu retrocesso ao país e principalmente à classe pobre.

Com a crescente onda de corrupção que assola o país, o erário tende a ficar escasso e sem condições de patrocinar investimentos importantes ao desenvolvimento nacional. O Poder Judiciário por sua vez, sofre com a falta de investimentos e estrutura adequada para atender uma cultura cada vez mais demandista:

Direito é tributário da política, da mesma maneira que um rio que se forma de outro e ganha traçado próprio, porém continua sendo água do rio de origem, como tal guardando toda a essência daquele sem o que não poderia existir. Em síntese, o direito é parte de uma ordem política (ou sistema político), e aquilo que ocorre à política reflete no direito (DERANI, 2008, p.2).

Portanto, a distorção econômicas em torno de uma justa distribuição de renda e um conseqüente desenvolvimento sustentável, acaba por confirmar um dado perverso na história, brasileira, qual seja, a de que os poder econômico faz da estrutura político-jurídica, um jogo de cartas marcadas que legitima seus interesses:

As graves distorções econômicas em torno da distribuição de renda, no Brasil, podem ser explicadas a partir de exemplos históricos: o escravismo, financiando a expansão açucareira; as estruturas jurídicas, permitindo a expropriação de riquezas auríferas e seu contrabando; o tráfico negreiro, etc. Toda essa atividade foi possível, inclusive, em face da alta concentração de renda em mãos de senhores de terra e de escravos que, em última instância, tornavam a financiá-la e a concentrar mais poder em benefício próprio (SILVA, 2004, p. 89).

Explica-se, assim, de que modo o poder econômico, quando neutraliza a atuação estatal e conseqüentemente os mecanismos democráticos de justiça, obstaculiza a efetivação de direitos primordiais e constitucionais, bem como o desenvolvimento do país.

\section{O PROBLEMA MULTIFATORIAL DA DEFICIÊNCIA DA JUSTIÇA}

A justiça brasileira, aqui entendida como um complexo de instituições públicas e até mesmo privada, a exemplo da advocacia, pois é essencial à administração da justiça, formada por agentes, procedimentos e equipamentos, possui uma agenda desafiadora, qual seja aplicar a norma ao caso concreto e materializar o desenvolvimento nacional.

Entretanto, são muitos os obstáculos a serem suplantados, além de que os investimentos são poucos e a falta de pessoal e tecnologia adequada aliados à crescente hiperlitigiosidade, torna o problema ainda mais crônico.

O ensino jurídico mecânico, ideológico e superficial pode ser visto como uma das primeiras causas deficitárias da justiça. Isso porque, inobstante o Brasil ser o país que mais possui faculdades de direito, no entanto, o atual ensino jurídico tem sido incapaz de formar, via de regra, pessoas que revolucionem o direito. 
A cultura "manualesca" preparada e dirigida a um público ávido por passar em concursos públicos e adquirir estabilidade e salários altos, tem sido responsável pela superficialidade do direito. Os alunos saem da faculdade repetindo fórmulas e teorias, não se preocupando em renovar a jurisprudência ou estudar a fundo as causas da precariedade de nossa justiça.

Os concursos e provas por sua vez, apenas privilegiam a memória, pois exigem que o candidato decore um universo de códigos, artigos e regimentos. Dessa forma, o alunado não faz do direito um importantíssimo instrumento de transformação social, mas um meio de se obter uma carteira de advogado ou um cargo público.

Nesse sentido, é a palavra de José Renato Nalini:

Saudável que a população queira se educar juridicamente, para conhecer seus direitos, poder usufruí-los e, simultaneamente, treinar o cumprimento de seus deveres. Mas o padrão de Faculdades de Direito em atividade, não difere muito daquele em vigor na Coimbra de 1827: aulas prelecionais, disciplinas compartimentadas, totalmente desvinculadas de uma visão holística. Mais significativo do que a estrutura preservada, todavia, é a concepção do que deva ser uma Faculdade de Direito (SILVEIRA \& MEZZAROBA, 2011, p. 128).

Outro fator subsequente que pode ser elencado é a precariedade da Administração Pública. O Estado dá um péssimo exemplo de "clientelismo judicial" por sua litigância habitual, haja vista que é recorrentemente demandado na justiça por não cumprir com suas obrigações.

Isso faz com que os governos não invistam na modernização do Poder Judiciário, pois é conveniente a eles a morosidade, o entupimento das vias judiciais e a falta de eficiência.

Ademais, um Estado que não respeita os princípios axiológicos da ética e da justiça, pode ser perfeitamente questionado com relação à legitimidade e validade de seus atos, bem como de sua própria natureza.

O retrocitado autor, pondera que:

O maior cliente do Poder Judiciário no Brasil é o próprio governo. [...] O Estado não cumpre as obrigações que o pacto republicano lhe impôs. Aquele que se considera prejudicado invoca o Estado-juiz para fazê-lo adimplir. O Estado se apropria dos bens dos particulares e não se preocupa em observar o preceito fundante que determina justa e prévia indenização em dinheiro. Outras vezes ocupa bens alheios sem o processo expropriatório, restando ao desapossado recorrer à ação de desapropriação indireta. Não paga os precatórios, nada obstante os privilégios que desfruta (SILVEIRA \& MEZZAROBA, 2011, p. 129).

Como falar em justiça e moralidade da Administração Pública, princípios basilares de um Estado que se pretenda Democrático e de Direito, se temos uma estrutura política viciada no litígio e despreocupada com o cumprimento de obrigações?

O Estado brasileiro caminha na contramão da Constituição Federal, pois além de não ser eficiente, eficaz e efetivo, obrigações a ele impostas, incentiva a pérfida prática jurídica adversarial.

Desse modo, estudar a natureza e o papel do Estado brasileiro, torna-se primordial na busca do desenvolvimento sustentável, pois se passa a desnudar as causas do subdesenvolvimento e da própria ineficiência 
estatal:

Este é um dos grandes problemas dos estudos jurídicos e constitucionais do Brasil na atualidade: a falta de uma reflexão mais aprofundada sobre o Estado. É necessário que os juristas retomem a pesquisa sobre o assunto, voltem a se preocupar com uma Teoria do Estado. Isto se reveste de maior importância no caso do Estado brasileiro, que, além de tudo, é subdesenvolvido. Conhecer, assim, os obstáculos à atuação do Estado brasileiro e buscar alternativas para superá-los é fundamental, em nossa opinião, na sua (re)estruturação para a promoção do desenvolvimento (BERCOVICI, 2005, pp. 42-43).

O Brasil tem um compromisso com sua gente e também com a própria ordem jurídica internacional, haja vista que é signatário da Carta de Direitos da Organização dos Estados Americanos (OEA). Tem, portanto, um dever ético de promover e realizar a justiça e o bem-comum da sociedade:

O desenvolvimento é responsabilidade primordial de cada país e deve constituir um processo integral e continuado para a criação de uma ordem econômica e social justa que permita a plena realização da pessoa humana e para isso contribua (OEA, 1948, Artigo 33).

Atualmente o Estado brasileiro tem deixado a desejar. Entretanto, é de se observar que a cultura da hiperlitigiosidade é um fenômeno que atinge outros agentes, de forma que se torna outro fator a contribuir com a deficiência da justiça brasileira.

As empresas não respeitam os direitos do consumidor. Investe-se milhões em propagandas falaciosas incentivando a população ao consumismo, para depois acionar muitos deles na justiça.

Usa-se a "sustentabilidade" como veículo para se atrair mais lucros, sem a menor preocupação com a ecologia, além de que produtos de péssima qualidade, lesões no peso do produto e informações incompatíveis com a embalagem, acabam por desaguar no Judiciário uma "enxurrada” de processos.

E, não pensemos que a população não tem sua parcela de culpa, pois muitos movidos pelo "ânimus lotérico”, ingressam muitas vezes com ações no Judiciário na esperança de se locupletar, mesmo sabendo não possuir direito algum.

Nas próprias faculdades de direito é ensinada a cultura adversarial, de forma a inflacionar cada vez mais a cultura demandista no Brasil. Nas palavras de Nalini:

É a escola que ensina a litigar. A educação jurídica é eminentemente adversarial. Desde os primeiros semestres, os alunos são treinados ao litígio. A prática jurídica se resume ao exercício da advocacia em juízo. Pouco se investe na formação de um profissional da prevenção dos conflitos, habilitado em pacificar, apto a conciliar, a propor a negociação ou a transação, além de inúmeras outras alternativas de resolução de conflitos que prescinda de uso da pesada e burocrática máquina judicial (SILVEIRA \& MEZZAROBA, 2011, p. 128).

Prosseguindo, a advocacia, inobstante ser essencial á administração da justiça, também possui sua parcela de contribuição para o mau funcionamento da justiça. Tal, pode ser visto na cultura hiperlitigiosa, em que o advogado não instrui seu cliente sobre os riscos e desnecessidade de se percorrer a via judicial.

Muitos advogados pensam apenas no lucro, e se esquecem que podem utilizar os meios consensuais de resolução de conflitos e cobrar pelo seu trabalho técnico e pacificador. 
Também há os profissionais antiéticos que procrastinam o processo com uso abusivo de recursos, cujo objetivo é ganhar tempo e dinheiro, pois cada peça demanda novo custo. Isso abarrota a máquina judicial que passa a operar além de seus limites, oferecendo ao cidadão uma tutela jurisdicional cada vez mais lenta.

Outro fator relevante no exame das concausas da precariedade da máquina judiciária, é o próprio corpo de serventuários da justiça. Funcionários que corporificam a própria ineficiência e burocracia ao impor normas e regimentos internos acima de dispositivos legais e constitucionais são grave óbice à eficiência da justiça.

Priorizam a letra fria da lei e cultuam as formas, esquecendo-se do fator primordial que é a própria justiça do caso concreto, sendo a processualística apenas um meio para se alcançar um fim.

Além de que, muitos serventuários, vivem de "cara amarrada", atendem mal ao povo e aos advogados, esquecendo-se que estão na instituição pública justamente para servirem ao povo. Como conseqüência, o Judiciário cai no descrédito e colabora para a perpetuação da injustiça:

[...] Como bem destaca Werneck Vianna, uma série de fatores necessitavam ser perscrutados perante a magistratura concreta com o fim de indagar qual o perfil do magistrado e até que ponto havia, de fato, a democratização da prática judicante. É preciso se indagar 'para que' e ‘a quem' o Poder Judiciário está servindo. Diferentemente dos militares e embaixadores, sob os quais a 'instituição' procede a uma contínua e reiterada domesticação e homogenização ideológica, munida, ademais, de mecanismo apto à exclusão do pensamento dissonante, na magistratura, por sua organização e história, essa possibilidade de uniformização resta presente [...], mas um tanto quanto difusa (ROSA, 2006, p. 247).

De igual modo, muitos juízes são extremamente burocráticos e apegados à forma da lei. Não hesitam em ordennar procedimentos que poderiam ser supridos doutra forma mais célere.

Há juízes que padronizam suas decisões, e no afã de cumprirem metas exclusivamente matemáticas, desconsideram as peculiaridades do caso concreto e impõem ao jurisdicionado um entendimento elitista e institucionalizado. Assim, se esquecem de aplicar a justiça ao caso concreto.

Nessa esteira, muitos magistrados não fazem justiça social, pois negligenciam as normas preceituais e axiológicas da Carta Magna, negando sua eficácia. Ainda há os que se apegam à literalidade da lei, numa exegese precária e positivista ideológica, reduzindo o direito ao simples texto legal.

O resultado é a desconfiança da população no poder da justiça, e o crescimento das críticas, fazendo da máquina judiciária alvo de protestos e ressentimentos. Nesse sentido, assevera mais uma vês José Renato nalini que:

O equipamento estatal denominado justiça é alvo de críticas em todo o mundo. [...] Os danos experimentados carregam larga dose de emoção e angústia. [...] Se isso ocorre no planeta como um todo, a situação brasileira reveste peculiaridades que intensificam a sensação de inexistir justiça. [...] O país abriga nichos de miséria a mais abjeta, em convívio com a riqueza nababesca e pródiga em sofisticação e superfluidades. Para os excluídos do banquete do consumismo a certeza é a de que o Judiciário serve aos ricos. Para os demais, mostra a sua face cruel: polícia, prisão, arbitrariedade e opressão (SILVEIRA \& 
MEZZAROBA; et al, 2011a, p. 126).

Um último item que revela a deficiência da justiça brasileira é a burocracia. Sabe-se que o Brasil é o país do protocolo, das taxas e do cartorialismo, de forma que o Poder Público desconfia a priori do cidadão, impondolhe uma verdadeira "via crucis" quando se trata de requisitar os serviços públicos.

No Judiciário a realidade não é muito diferente, pois boa parte de seus membros ainda está muito apegada à estrita obediência à formalística dos atos. Muito tempo e dinheiro se perdem com o preenchimento de papéis, assinaturas, atos, enfim.

Não se duvida que a Administração Pública precise agir com cautela e segurança, exigindo documentos comprobatórios, assinaturas, taxas, etc. Porém, o que se questiona é a exacerbação na exigência de procedimentos e documentos que poderiam ser suprimidos, criando-se um corpo de funcionários munidos de canetas, carimbos, chancela e poder de liberação ou não do ato.

O funcionalismo público brasileiro não tem fama de ser eficiente ou acolhedor, muitos há que agem de má vontade, o que acaba por se criar dificuldades e procedimentos cada vez mais complexos e retardatários, quando não suprimidores de direitos.

Inobstante a Constituição Federal garantir a todos os brasileiros o acesso à justiça (art. 5o XXXV), aqui entendido não apenas o ingresso ao Judiciário enquanto instituição física, mas também o direito de receber uma prestação jurisdicional célere, qualitativa e justa:

É inconcebível que o jurisdicionado não consiga obter para o seu conflito uma decisão rápida e célere por parte do Estado. Não basta garantir-se ao jurisdicionado o acesso ao Judiciário. Mais do que isso é necessário garantir a possibilidade de obter uma decisão justa, célere e eficaz. (SILVEIRA \& MEZZAROBA; et al., 2011, pp. 18-19).

A burocracia jurídica, portanto, emperra o bom desempenho da prestação da tutela jurisdicional, e impede que o valor "justiça” seja realizado.

O problema se torna ainda mais grave quando se trata de presidiário, pois este muitas vezes fica sob o arbítrio e o poder do diretor do presídio. São notórias as condições vexatórias, precárias e violentas a que os presos são submetidos, tendo inúmeros direitos violados, principalmente no que tange sua dignidade humana.

Nada obstante, a Lei de Execução Penal determinar que é dever do juiz da execução inspecionar mensalmente os presídios a fim de tomar providências para seu adequado funcionamento (art. 66, VII), impera na realidade a lei da violência e da degradação humana. Prefere-se requisitar um relatório junto à diretoria do estabelecimento prisional, o qual não relata com integralidade as reais condições do preso e do local. Assim, este, pela burocracia, não consegue acessar o diretor do presídio, tampouco o juiz da causa.

Ao se alijar as pessoas de seus direitos e humanidade, o resultado é uma maior criminalidade e revolta. Enfim, todo o elenco de fatores aqui mencionado, colabora para subtrair a característica democrática do Brasil, e 
afundando-o ainda mais no subdesenvolvimento.

\section{A IMPORTÂNÇIA DA EFETIVAÇÃO DOS DIREITOS FUNDAMENTAIS INDIVIDUAIS E SOCIAIS}

A vigente Carta Política enumera uma série de direitos humanos, sob a classificação de "direitos fundamentais", os quais são imprescindíveis à realização da pessoa humana, bem como ao desenvolvimento sustentável.

Esses direitos fundamentais, individuais e sociais, constituem um patrimônio jurídico amplo e profundo que abarca igualdade, proteção à personalidade, liberdade física e intelectual, direitos civis, políticos e acesso à justiça, bem como educação, saúde, trabalho, mordia, dentre outros.

Tal é a importância desses direitos que, uma vez concretizados possuem o poder de realizar o ser humano, desenvolvendo seu potencial e afirmando sua dignidade enquanto ser possuidor de elevado teor ontológico.

O homem pode ser mais do que efetivamente é, tem a capacidade de superação e criação de novas formas de vidas baseadas na profundidade, qualidade e transcendência:

[...] Direitos humanos servem para tratar assuntos referentes a direitos individuais, coletivos, sociais, econômicos, violência, miséria, alem de outras concepções, sob a alegação de diretrizes para a proteção da dignidade da pessoa humana. O fato é, no entanto, que nesta defesa da dignidade da pessoa humana, os direitos humanos adquiriram uma força extraordinária, fruto de uma linguagem consistente, instalado no mundo Ocidental, na qual a positivação dos direitos indica, por exemplo, se um Estado pode ou não ser reconhecido como democrático ou se assume ares de barbárie (BAEZ; SILVA \& SMORTO; et al., 2012, p. 175).

Por conseguinte, torna-se extremamente relevante falar em direitos humanos ou fundamentais na atualidade - realçando que, por uma questão terminológica e classificatória, o primeiro termo refere-se aos acordos subscritos nos Tratados Internacionais, ao passo que o segundo, se encontra consubstanciado nas Constituições - haja vista as condições sub-humanas a que muitos se encontram submetidos.

Uma análise perfunctória revela que nos quatros cantos do planeta prevalecem a alienação, exploração, pobreza, fome, violência, dentre outros. Esse quadro, extremamente caótico, põem em confronto o paradoxo criado pelo homem contemporâneo, qual seja a supressão da ética e da moral, pelo fato de as autoridades políticas, jurídicas e econômicas permitirem a degradação humana, ao mesmo tempo em que a ciência e a tecnologia foram capazes de revolucionar a vida humana:

[...] Não deixa de ser estranho que no momento em que a globalização, sobretudo econômica, torna-se um fenômeno universal, se proclame por toda parte a impossibilidade 
teórica de uma ética universal; muito estranho porque a situação atual, e em nível mundial, está marcada fundamentalmente por quatro vergonhas político-morais que afetam gravemente a existência de todos: a fome e miséria; a tortura e a contínua violação da dignidade humana; o crescente desemprego e disparidade na distribuição de renda e riqueza; e a ameaça de destruição da humanidade pelo perigo de uma possível guerra nuclear e pelo desequilíbrio ecológico (BAEZ; SILVA \& SMORTO; et al., 2012, p. 161).

No caso brasileiro a situação ainda se reveste de uma peculiaridade, pois os fatores históricos e culturais da injusta distribuição de renda e conseqüente manutenção da pobreza, aliados ao problema da crescente corrupção, divide o país em dois pólos diametralmente opostos. Assim, e um lado se encontra a parte agraciada por uma vida qualitativa, e de outro, milhões de pessoas vivendo uma "subvida", alijados de qualquer conforto, oportunidade e condições adequadas.

Portanto, quando se fala em dignidade da pessoa humana e desenvolvimento sustentável, tem-se em mente, o que a Constituição chama de "sadia qualidade de vida" (art. 225), a qual, certamente é derivativa do conjunto de direitos elencados nos arts. $5^{\circ}$ e $6^{\circ}$. Esses direitos não apenas denotam a face democrática do Estado brasileiro, como também, humana, pois enuncia o Estado como principal agente promotor da justiça e do desenvolvimento sustentável.

Daí o inquestionável relevo que se deve dar à Constituição, bem como à uma hermenêutica axiológica aplicada como resolução dos problemas sociais:

No Direito contemporâneo, a Constituição passou a ser compreendida como um sistema aberto de princípios e regras, permeável a valores jurídicos suprapositivos, no qual as ideias de justiça e de realização dos direitos fundamentais desempenham um papel central (BARROSO, 2015, pp. 355-356).

Depreende-se que, se o filtro hermenêutico da Constituição Federal é a dignidade da pessoa humana, então esse valor deve prevalecer sobre todo o restante, de modo que a efetivação concreta dos direitos fundamentais, quer sejam individuais ou coxeias, torna-se o parâmetro para medir o nível de justiça, democracia e humanidade do Estado brasileiro.

Ocorre que a despeito da prescrição de relevantes direitos, a realidade brasileira revela que há um distanciamento gigantesco entre a abstratividade da lei e a vida social concreta. Tal fato realça o caráter extremamente simbólico e ideológico da Constituição Federal.

A baixa aplicabilidade das normas constitucionais colabora para que a qualidade de vida do cidadão seja sempre inferior ao que sua dignidade merece. Assim, a falta de alimentação adequada, educação qualitativa, trabalho gratificante e bem remunerado, saúde, moradia, transporte, bem como os direitos individuais de liberdade e igualdade, tornam-se uma ilusão, que separam as classes sociais, servindo como símbolo ideológico de dominação e manutenção do "statu quo":

De acordo com Luigi Ferrajoli, o modelo jurídico contemporâneo, "embora atuando como parâmetro de legitimidade do sistema, não passa de um instrumento de mistificação 
ideológica, considerando-se a sua ausência de efetividade”. A justificativa para a existência do sistema legal passa a ser, então, de forma exacerbada, sua função eminentemente simbólica (GABARDO, 2003, p. 74).

Portanto, albergar direitos essenciais ao desenvolvimento humano, mantendo-os tão somente no lócus formal, sem adotar mecanismos efetivos para sua concretização, denota uma estratégia perversa do Estado, que ilude o cidadão e procura manter a ordem social por meio de mitos jurídicos.

À sociedade interessa tanto o reconhecimento jurídico dos direitos fundamentais, mas principalmente sua realização, pois a população carece adentrar á uma espécie de vida em que a dignidade, a satisfatividade e a qualidade sejam elementos tangíveis.

Para se atingir tamanho objetivo, necessita-se quebrar o paradigma reinante, substituindo-se a ideologia pela verdade, a má-vontade por uma vontade política e jurídica honesta, justa, coletiva e efetiva, de forma que o conjunto de direitos fundamentais seja uma realidade palpável:

Nunca devemos nos esquecer de que o sucesso da ideologia dos direitos humanos é paralelo ao começo da grande exploração burguesa, que transformou o mundo contemporâneo. Esse paradoxo esconde, como todos os paradoxos, uma verdade que deve ser revelada. Uma questão são as palavras e a retórica política, e outra, bastante diferente, a funcionalidade social das idéias que aquelas representam (ROBLES, 2005, p. 75).

Diante de todo o exposto, emerge a pergunta central: haverá esperança de justiça concreta, eficiente, célere e qualitativa, para a população carente na atual sociedade brasileira?

O país possui uma economia forte, fartos recursos naturais, ocupa uma posição média na diplomacia geopolítica e presença considerável no comércio internacional, reunindo, portanto, condições suficientes para o desenvolvimento que trará em seu bojo alta qualidade na prestatividade dos serviços públicos.

A seguir, será delineada uma rápida análise do Poder Judiciário, considerado uma peça de fundamental importância na efetivação de uma plataforma sustentável e na realização de uma justiça célere, efetiva e qualitativa.

\section{PODER JUDICIÁRIO E JUSTIÇA SOCIAL NO BRASIL}

O Poder Judiciário é inequivocamente um dos sustentáculos da democracia brasileira, sendo na atualidade o mais próximo da população, o menos incidente em fatores de corrupção, e possuindo a enorme vantagem de tornar realidade os direitos preconizados pela Constituição Federal por meio da aplicação prática da norma jurídica.

Com a retração - e a larga corrupção evidenciada nos meios de comunicação - dos poderes Executivo e Legislativo, o Judiciário assumiu uma posição de maior proeminência no cenário nacional. Adotou-se uma postura mais dinâmica para buscar resolver questões de alto relevo surgidas na sociedade. 
Foi com a máxima utilização do princípio da "Reserva do economicamente possível", utilizado em larga escala - e às vezes de forma automática - pelo Executivo, que se deslocou para o Judiciário uma enorme quantidade de demandas da mais variadas possíveis, como solicitação de remédios, tratamentos médicos negados por planos de saúde, educação, união homoafetiva, direito de greve do servidor público, fidelidade partidária, dentre outros.

Os pedidos, em suma, tinham como pano de fundo a dignidade da pessoa humana, vetor máximo para a interpretação da Carta Magna. O Judiciário surge então, como uma "tábua de salvação" àqueles que não tem condições econômicas de arcar com a realização dos elementos mais básicos e essenciais à vida humana, a exemplo da saúde, educação, moradia, etc.

Nesse contexto, emergiram as críticas de que o Ativismo Judicial ou até mesmo a Judicialização da Política conferiria ao Poder Judiciário um extrapolamento de suas competências, alegando-se os riscos de uma "Supremocracia", aqui neste trabalho entendida como uma espécie de ditadura do Supremo Tribunal Federal, e consequentemente, do aparelho judicial como um todo.

Uma das críticas dirigidas à postura macro dinâmica do Judiciário, e na maioria das vezes ao Supremo Tribunal Federal, é que haveria enormes riscos à democracia quando uma instituição não eletiva como o Judiciário suprimisse decisões do Poder Executivo e até do Legislativo, os quais em tese teriam o "carimbo" da legitimidade, haja vista terem sido eleitos pela vontade de milhões de cidadãos.

Ocorre que na Constituição Federal, cuja guarda é dirigida ao STF, o Judiciário é um Poder equivalente, independente e atua de forma harmônica com os demais na consolidação da democracia e no desenvolvimento do país.

Deve a crítica contramajoritária ser mitigada, à medida que se percebem as grandes lacunas deixadas pela péssima qualidade da representatividade política dos poderes Executivo e Legislativo.

A não representatividade dos interesses sociais e a corrupção institucionalizada abriram considerável abismo entre esses dois poderes e a sociedade, levantando-se, consequentemente, grande margem de dúvida quanto à sua legitimidade.

Destarte, a despeito das críticas acima tecidas, dos muitos erros cometidos pelo Poder Judiciário em sua atividade judicante, do alegado desequilíbrio na Teoria da Tripartição do Poder, percebe-se que o ativismo judicial possui aspectos positivos e negativos.

Entretanto, o Judiciário ao aplicar a norma constitucional ao caso concreto está cumprindo seu função e obrigação constitucional, realizando seu papel de instituição democrática e desempenhando seu dever ético e moral, colaborando assim, para a efetivação da justiça e do desenvolvimento sustentável. 
O Judiciário é responsável pela realização de uma plataforma sustentável à medida que realiza a justiça social, ou seja, que torna possível o desenho social e desenvolvimentista previsto na Constituição Federal.

Uma Carta de Direitos extremamente formal e de cunho simbólico não serve aos interesses da nação, mas de pequenos grupos que concentram grande poder político e econômico.

Ao conjunto da sociedade importa que o Judiciário, órgão encarregado de promover a justiça efetiva construa a ponte entre a formalidade jurídica e a concretude social. Nessa linha, pondera José Renato Nalini:

Entre o Brasil real e o Brasil formal existe um fosso aparentemente instransponível. A Constituição da República propõe a instituição de um Estado Democrático destinado a assegurar o exercício dos direitos sociais e individuais. Erige a igualdade e a justiça, ao lado de outras promessas, como valores supremos de uma sociedade fraterna, pluralista e sem preconceitos. [...] Aquela que mais acreditou no Poder Judiciário e que criou instrumentos de facilitação de acesso. Por sinal que a multiplicação das demandas após 1988 é considerada uma das consequeências do apreço que o constituinte devotou à justiça (SILVEIRA \& MEZZAROBA; et al., 2011, pp. 126-127).

Enquanto as normais constitucionais permanecerem no âmbito formal, o jurisdicionado terá apenas uma mera expectativa direito, dependendo, portanto, de que o Judiciário se encarregue de efetivar os direitos fundamentais individuais e sociais.

Assim, não há que se falar em ativismo judicial - ao menos no sentido pejorativo do termo - quando o Judiciário dá à norma um sentido concreto, transformando a realidade social. Esse é o fim maior do Poder Judiciário, qual seja, promover a justiça em sentido amplo, axiológico e concreto, e a justiça social.

O corpo preambular do Texto Magno, o qual indica os fundamentos objetivos da República brasileira, assevera que esta deve concretizar os direitos sociais e individuais, e elege a igualdade e a justiça como valores supremos.

Tem-se que o Judiciário, atuando como um braço forte do Estado, pode e deve corrigir as graves distorções produzidas pelos excessos do sistema capitalista, de forma a equilibrar e conciliar os diferentes interesses entre as classes sociais.

Isso pode ser feito por meio da regulação dos contratos, principalmente os de adesão, corrigindo-se o desrespeito à autonomia da vontade; aplicando a norma para punir o abuso do poder econômico e os crimes ambientais e contra a economia popular; impondo- se às empresas o cumprimento de sua função social de recolher imposto, respeitar os direitos dos trabalhadores, bem como sua dignidade e o meio ambiente natural.

De igual modo, a justiça se realiza ao se velar pela vulnerabilidade e hipossuficiência do consumidor; por meio do respeito à liberdade e proteção da integridade psicológica e física do cidadão, bem como se aplicando ao caso concreto as normas constitucionais que dizem respeito aos direitos essenciais como alimentação, saúde, educação, trabalho com salário mínimo decente, moradia, profissionalização, dentre outros. 
Esse conjunto de direitos retrocitado supre as necessidades psicofísicas, desenvolve as capacidades e realiza o ser humano, efetivando na prática um modelo ético, justo e humano de sociedade sustentável.

A Constituição Federal tem como princípio a justiça social, elencando uma série de procedimentos interventivos na ordem econômica, a fim de que haja uma prevalência da dignidade da pessoa humana sobre o patrimônio material:

A ordem econômica, fundada na valorização do trabalho humano e na livre iniciativa, tem por fim assegurar a todos existência digna, conforme os ditames da justiça social, observados os seguintes princípios: [...] função social da propriedade; [...] defesa do consumidor; defesa do meio ambiente; redução das desigualdades regionais e sociais; busca do pleno emprego (Art. 170, "caput" e incisos III, V, VI, VII e VIII).

Depreende-se que a missão e agenda do Poder Judiciário são desafiadoras, haja vista que este deve implantar os ditames da justiça social. Isso porque, a justiça não é um simples termo axiológico, filosófico e jurídico, mas também um conceito profunda e intrinsecamente relacionado com a dimensão concreta econômica, política e social do ser humano:

Na teoria da justiça, a abordagem platônica de uma sociedade justa ressurge e inaugura uma perspectiva interdisciplinar para a análise da justiça, não mais apenas moral e jurídica, mas econômica, política e social (TAVEIRA; et al., 2005, p. 186).

Num país de profundos contrastes culturais, sociais e econômicos como o Brasil, o Poder Judiciário, a fim de cumprir constitucionalmente seu papel, terá que enfrentar a ambição do poder econômico, a má-vontade política do Poder Executivo, e as constantes omissões legislativas.

Para tanto, impende também destacar que o paradigma atual de baixa aplicação da Constituição brasileira, bem como a omissão dos magistados e a falta de maior eficiência na instituição como um todo, precisa urgente ser substituido por uma mentalidade renovada, dinâmica e comprometida com os valores éticos, sociais, humanos e de justiça.

Evidentemente, existem outros fatores que interligados e aplicados a um novo paradigma de eficiência judicial, podem perfeitamente potencializar o órgão judiciário na produção de uma justiça acessível, célere, efetiva, qualitativa, social e humana.

\section{CAMINHOS SEGUROS À EFICIÊNCIA DA JUSTIÇA BRASILEIRA}

O princípio da eficiência, insculpido no artigo 37 da Constituição brasileira deve abarcar os meios corretos, o estabelecimento e alcance dos resultados devidos, e a transformação da realidade social, a fim de se otimizar as funções estatais e construir uma sociedade sustentável.

Desse modo, utilizou-se o termo eficiência dentro de uma conceituação semântica mais ampla, 
conforme empregado nas ciências da administração.

A eficiência pretendida neste artigo engloba, portanto, três características, quais sejam, fazer algo da melhor e mais correta forma possível; empregar os instrumentos certos na busca do resultado devido e pretendido; e, por fim, transformar a realidade concreta por meio do objetivo alcançado.

O Estado deve realizar a administração da coisa pública da melhor e mais correta forma possível. Isso quer dizer que deve gerir com eticidade, competência e qualidade o erário, de forma a distribuir equitativamente as verbas necessárias à saúde, educação, transporte, moradia, etc.

Tem-se que o objetivo primordial a ser alcançado pelo Estado é a realização do bem comum de todos, construindo-se uma sociedade sustentável, em que haja uma autêntica e sadia qualidade de vida. Para isso, há que se primar por uma hermenêutica que priorize a interpretação e aplicação das normas preceituais e principiológicas constitucionais.

A aplicação da norma constitucional pelo Poder Judiciário constitui-se numa metodologia científica segura para se promover o desenvolvimento, e assim, diminuir substancialmente as desigualdades sociais e regionais, e implantar serviços públicos de qualidade e o acesso à justiça.

Destarte, com a realização do potencial da pessoa humana e com a criação de um novo modelo de sociedade, calcada na justiça, fraternidade e solidariedade, ter-se-á inicio a uma existência mais digna, profunda e significativa, alcançando-se, desse modo, a transformação da realidade que se apresenta nos parâmetros atuais.

Entende-se que a eficiência não é uma alternativa, mas uma necessidade premente do Estado brasileiro:

o Princípio da Eficiência exige que a atividade administrativa seja exercida com presteza, perfeição e rendimento funcional. É o mais moderno princípio da função administrativa, que já não se contenta em ser desempenhada apenas com legalidade, exigindo resultados positivos para o serviço público e satisfatório atendimento das necessidades da comunidade e seus membros (MEIRELLES, 2002, p. 94).

Considerando que o problema da ineficiência da justiça está ligado a diversas causas, a possível solução deve passar, igualmente, pela adoção de um conjunto de medidas que visem o aperfeiçoamento do aparelho judicial.

Abaixo, elenca-se as principais providências que devem ser implantadas para não apenas desafogar o Judiciário, como fazê-lo operar de forma dinamogênica.

\section{Reforma do Ensino Jurídico}

De plano cumpre dizer que a quebra de um paradigma obstaculizador do bom funcionamento da justiça implica em atingir seu nascedouro, ou seja, desconstruir as ideologias (sentido de falsificação da realidade) 
ensinada nas academias.

Mais do que implantar uma nova metodologia no que tange ao ensino do direito, necessita-se construir uma nova educação jurídica, haja vista ser esta última um conceito mais amplo, pois compreende o conjunto de técnicas, processos e métodos de socialização, sensibilização e instrução do indivíduo.

Destarte, é preciso criar uma cultura jurídica capaz de mudar as mentalidades existentes, em que o estudante do direito aprenda a criar soluções adequadas a novos tempos e contexto, de forma que urge a libertação das teorias meramente abstratas, ultrapassadas ou mitológicas.

O estudante de hoje precisa fazer do direito um relevante instrumento de inclusão social, primando pela paz, justiça, desenvolvimento e efetividade do direito. De igual modo, é necessário extirpar do meio jurídico a cultura do litígio e a ideologia de que o conflito deve necessariamente ser judicializado.

É preciso incentivar a pacificação e os e meios consensuais e extrajudiciais de resolução do conflito. O péssimo costume de judicializar toda e qualquer questão da vida social precisa ser substituído por uma postura mais flexível, dialógica e pacífica.

A sentença ou acórdão põem fim ao litígio, mas não ao problema. Assim, é fundamental a participação dos profissionais do direito na conscientização da população.

\section{Otimização da Administração Pública}

Cumpre dizer que o Estado tem a obrigação de ser sustentável, ou seja, de realizar o bem comum e elevar a dignidade da pessoa humana. Isso ele deve fazer por meio de uma administração eficiente, ética e humana.

O cuidado em administrar com zelo e competência o dinheiro público deve perpassar as três esferas da administração pública, de forma a tapar o ralo da corrupção e desperdício e investir na criação e implantação de políticas públicas voltadas à consecução de uma vida digna, bem como na efetivação de uma excelência prestacional de serviços.

Para tanto, deve-se enxugar a máquina pública, corrigir os excessos da folha de pagamento do funcionalismo público, revisar contratos onerosos à administração e controlar os gatos públicos.

O Poder Executivo, encarregado das finanças públicas, deve viabilizar e melhorar a estrutura judicial construindo mais defensorias públicas, implantando fóruns nas periferias, nomeando mais profissionais do direito e incrementando as instituições judiciais, tais como delegacias, fóruns, defensorias e promotorias com modernas tecnologias.

É notório que outro grave problema a ser corrigido na Administração Pública é o déficit democrático e 
ausência de participação efetiva da população nas instâncias do poder.

As brechas e ideologias presentes no sistema democrático permitem que os "profissionais da política" se elejam com determinada plataforma política, mas assim que assumem o poder deixam de lado os interesses da sociedade para atender os grupos econômicos que financiaram sua carreira e campanha.

Destarte, urge que a sociedade civil comece a participar de forma direta e efetiva na tomada de decisões importantes, pois o povo na qualidade de legítimo detentor do poder e profundo conhecedor das mazelas sociais, saberá dar uma melhor destinação ao erário em determinados casos.

Alegações executivas de impossibilidades econômica e financeira seriam menos usuais se o próprio povo decidisse sobre qual o percentual de investimento que deve ser dirigido a alguns setores estratégicos, como saúde e educação. Convém à sociedade saber o quanto o Estado verdadeiramente arrecada e como o governo administra o dinheiro oriundo dos tributos.

Por conseguinte, uma vez que o Poder Executivo cumprisse eficientemente seu dever de amparar o cidadão, as ações judiciais diminuiriam consideravelmente. Assim, faz-se necessário que as portas dos órgãos estatais e suas finanças sejam abertos a quem os paga.

A excelência na prestação do serviço público só ocorre com uma efetiva e direta participação da sociedade na coisa pública. De sorte que o status de Estado "democrático" e de "direito", precisa necessariamente da participação popular nas suas instâncias decisórias e de poder:

O principal critério para determinar se um sistema democrático funciona normal e eficientemente é a participação consciente do público no processo da tomada de decisões políticas, o público deve aderir razoavelmente a certas idéias e decidir frente a um conjunto de alternativas (MANELI, 2004, p. 90).

Um simples voto de confiança dado pelo cidadão mediante uma campanha eleitoral propagandista, mercadológica e ideológica não é suficiente para se garantir todos os aspectos positivos conferidos pela democracia. Até porque numa sociedade extremamente estratificada e dominada pelos grupos que detém o poder político e econômico, como é o caso do Brasil, a vontade popular é facilmente manipulada:

Não há democracia sem participação. De sorte que a participação aponta para as forças sociais que vitalizam a democracia e assinam-se o grau de eficácia e de legitimidade no quadro social das relações de poder, bem como a extensão e a abrangência desse fenômeno político numa sociedade repartida em classes ou em esferas distintas e categorias de interesses (TAVEIRA; et al., 2005, p. 427).

Portanto, os governos não podem fazer do Estado e seus recursos um comitê para realização de seus interesses pessoais. A participação popular dilui o autoritarismo, ao mesmo tempo em que força os governantes a se enquadrem na lei. Isso também pode fazer com que se diminua a habitualidade litigiosa do Estado, forçando-o a cumprir seus compromissos:

O Governo precisa adotar uma postura jurídica preventiva de litígios. Não pode atuar à 
margem da lei, com resquícios de autoritarismo, com ignorância manifesta de textos legais e, principalmente, do comportamento ético exigível a quem atua em nome do povo e é por este remunerado (SILVEIRA \& MEZZAROBA; et al., 2011, p. 141).

A participação direta e efetiva do povo na coisa pública, não apenas confere maior legitimidade, transparência e democracia ao Estado, como atribui à sociedade a devida responsabilidade pelas decisões tomadas.

Já é tempo de a sociedade se politizar e se conscientizar de seus deveres e direitos, adquirindo uma mentalidade participativa, supervisionadora e reivindicante. Tal postura inibe e diminui consideravelmente a ineficiência, corrupção e desmandos do Poder Executivo.

\section{Potencialização e Revolução do Poder Judiciário}

Os processos de aprimoramento e adequação da máquina judiciária, a fim de que esta ofereça uma prestação jurisdicional célere, efetiva e qualitativa, passa primeiro pelo fator humano. O Judiciário é composto por seres humanos que cuidam de seres humanos.

É preciso que o "corpo da magistratura” adquira um "espírito” voltado para a consolidação concreta do princípio da dignidade humana. Isso se vê numa postura de respeito ao cidadão, tanto na tratativa pessoal quanto no julgamento da lide.

Assim, cada processo representa uma vida, de forma que o princípio da razoável duração do processo, a análise conjunta e ampla de todos os argumentos deduzidos na inicial, e os valores constitucionais, não podem ser suprimidos em nome do excesso de feitos.

O magistrado precisa corresponder à confiança e esperança do cidadão comum, decidindo muito próximo da objetividade, rejeitando os procedimentos burocráticos e velando pela aplicação das normas constitucionais.

Se cumprir com sensibilidade, ética e sabedoria seu mister, o juiz pode ajudar a reestruturar a sociedade, fazendo dela um lugar melhor para se viver. Precisa se desprender das garras da ideologia, das imposições política e econômica impostas por determinados grupos oligárquicos, não tendo nenhum receio de desagradá-los.

Há que se considerar que o magistrado deve conhecer a realidade política, social e econômica do país, bem como as mazelas de uma sociedade fria, estratificada e injusta. Munido de uma consciência crítica e humana, ele pode ajudar a restabelecer a dignidade de homens castigados por um sistema político insensível e desumano.

A competência ética, justa e humana do juiz pode diminuir a dor de seus semelhantes e aumentar a paz e a confiança nas instituições, há muito desgastadas pela corrupção e pelo desprezo aos mais pobres. O Judiciário e a Justiça tornam-se na atual conjuntura a única esperança daqueles que já perderam a fé no Executivo, Legislativo e 
demais instituições públicas e privadas, as quais não enxergam sua importância:

$\mathrm{O}$ juiz sabe que, naquele espaço que the foi reservado para atuar, ele pode ser um fator de redenção de seu semelhante. Ele tem condições de produzir a melhor justiça humana possível, de restituir ao lesado não apenas aquilo que de seu patrimônio jurídico foi subtraído, mas a esperança de que nem tudo está perdido e a confiança nos instrumentos postos à disposição da comunidade para resolver toda espécie de conflito (SILVEIRA \& MEZZAROBA; et al., 2011, p. 144).

Outro elemento importante na busca de uma justiça eficiente, trata-se de um pesado investimento tecnológico do Judiciário. Em tempos de modernas inovações, a máquina judiciária precisa se atualizar, desfazendo-se dos procedimentos e equipamentos obsoletos e causadores de retardamento e morosidade.

É preciso ter em vista que um mundo cada vez mais globalizado exige que o direito acompanhe as constantes evoluções tecnológicas, com o fito de garantir a correta aplicação da lei e, por conseguinte, atingir o ideal de justiça e de promoção da paz social. A sociedade contemporânea reclama o aproveitamento das novas tecnologias para efetividade da prestação jurisdicional. Nesse sentido, o presente trabalho aponta um panorama sobre a informatização do Poder Judiciário (SILVEIRA \& MEZZAROBA; et al., 2011, p. 67).

Um último elemento na construção de um Judiciário eficaz é justamente a importância de se conscientizar os magistrados de sua nobre e relevante missão: concretizar a justiça e a justiça social pela aplicação prática da norma constitucional, seja na sua espécie preceitual ou axiológica.

É inconcebível que a Constituição Federal assuma uma função simbólica e perca de vista a realidade factual e os valores que defende, os quais devem servir de guia diretivo ao juiz em sua atividade intelectiva e interpretativa.

O magistrado pode e deve ser um agente de realização da justiça, à medida que ele tem liberdade interpretativa e mecanismos de coerção para que a norma produza todos os seus efeitos.

Destarte, a realização de uma sociedade sustentável passa pelo poder decisório do juiz. A Constituição Federal já estabeleceu os valores, regras, metas e o desenho de uma sociedade justa e solidária. Portanto, em sua atividade judicante o juiz há que observar que a realização dos direitos fundamentais individuais e sociais são imprescindíveis á um Estado democrático.

O legislador constituinte confiou às mãos do juiz importante tarefa, haja vista que esses direitos não se efetivarão automaticamente.

\section{CONCLUSÃO}

À guisa de conclusão, impende dizer que a despeito de todos os problemas que o Brasil atravessa, a efetividade dos direitos fundamentais e sociais representa o resgate da dignidade da pessoa humana.

Isso porque, a voracidade de um poder econômico perverso e a má-vontade política dos administradores 
da coisa pública colaboram para que a classe operarial sofra todas as conseqüências de uma gestão descompromissada com os valores constitucionais.

Nesse passo, verificou-se que a retração dos poderes Executivo e Legislativo, conferiu ao Poder Judiciário certa proeminência, que ele precisa aproveitar em beneficio coletivo. As críticas tecidas à uma postura mais dinâmica do Judiciário são inócuas, pois a Constituição Federal o coloca em pé de igualdade e legitimidade perante os outros poderes.

O Judiciário é o poder mais próximo da sociedade civil, e na atual conjuntura, aquele que melhores condições possui de construir uma sociedade sustentável ao aplicar na prática a norma constitucional.

Entretanto, a problemática levantada foi que a prestação da tutela jurisdicional é precária, morosa e muitas vezes ineficiente, de forma que o problema possui um conjunto de causas. Isso atribui à Carta Magna um papel ideológico e reforça o estereótipo de uma sociedade injusta, insensível e produtora de mitos sociais.

Constatou-se que tal situação é deveras preocupante, pois se analisou de forma cautelosa como os direitos fundamentais é condição de possibilidade da realização humana e construção de uma sociedade justa, solidária e fraterna.

À posteriori se analisou que o Poder Judiciário também é responsável pela implementação de um novo modelo de vida, haja vista que tem o poder de aplicar as normas constitucionais, preceituais e axiológicas, ao caso concreto, sendo tal movimento essencial à reestruturação e "desideologização" do ordenamento jurídico.

Considerando que o problema da ineficiência judicial é multifatorial, a hipótese apresentada como mais adequada constituiu-se no elenco de várias medidas como implantação de uma nova cultura jurídica voltada à inovação e pacificação; otimização da Administração Pública e potencialização do Judiciário, por meio da humanização, implante de tecnologias e aplicação efetiva das normas altas.

Esses elementos são necessários e suficientes à construção de uma plataforma sustentável, propiciadora de uma vida profunda, produtiva e cheia de significado e realização.

\section{THE EFFECTIVENESS OF INDIVIDUAL AND SOCIAL FUNDAMENTAL RIGHTS AND HOPE IN BRAZILIAN JUSTICE}

\section{Abstract}

The present theme: "effectiveness of fundamental rights and hope in justice" is justified before the precarious 
Brazilian political and socioeconomic framework. Politics and economics have distanced themselves from constitutional and social values. The current situation shows that the constitutional norms are relegated to a merely symbolic role, which is why a more dynamic stance is demanded of the Judiciary Power, aimed at meeting the interests of society. The epistemological cut is given by an analysis of the multiple causes and effects of the deficiency of the judicial machine, an instant in which the problem emerges if it is possible to have hope of Justice in the face of the defaults, slowness and inefficiency of the State. Thus, using a deductive and critical methodology of reality, having as theoretical framework innovative legal theories, a hypothesis will be presented that responds to the problems identified, bringing hope to the jurisdiction and restoring its trust in the Public Power and its efficiency. It aims to show the gaps of the system and to point out that the Judiciary is the most secure access at the moment.

Keywords: Fundamental Rights. Efficiency.Judicial Power.

\section{REFERÊNCIAS BIBLIOGRÁFICAS}

BAEZ, Narciso Leandro Xavier; SILVA, Rogério Luiz Nery da; SMORTO, Guido (Organizadores), et al. Os desafios dos Direitos Humanos Fundamentais na América Latina e na Europa. Joaçaba: Unoesc, 2012. BARROSO, Luís Roberto. Curso de Direito Constitucional Contemporâneo: Os Conceitos Fundamentais e a Construção do Novo Modelo. 5 ed. São Paulo: Saraiva, 2015.

BERCOVICI, Gilberto. Constituição econômica e desenvolvimento - uma leitura a partir da Constituição de 1988. São Paulo: Malheiros, 2005.

CATANI, Afrânio Mendes. O que é capitalismo. São Paulo: Brasiliense, 1984.

DERANI, Cristiane. direito ambiental econômico. São Paulo: Saraiva, 2008.

GABARDO, Emerson. Eficiência e Legitimidade do Estado: uma análise das estruturas simbólicas do direito político. Barueri: Manole, 2003. 
MANELI, Mieczyslaw. A Nova Retórica de Perelman. Filosofia e Metodologia para o Século XXI. Barueri: Manole, 2004.

MEIRELLES, Hely Lopes. Direito Administrativo Brasileiro. São Paulo: Malheiros, 2002.

ROBLES, Gregorio. Os Direitos Fundamentais e a Ética na Sociedade Atual. Barueri: Manole, 2005.

ROSA, Alexandre Morais da. Decisão Penal: A Bricolage de Significantes. Rio de Janeiro: Lumen Júris, 2006.

SILVA, Guilherme Amorim Campos da. Direito ao Desenvolvimento. São Paulo: Método, 2004.

SILVEIRA, Vladmir Oliveira da (coordenação); et al. Empresa, funcionalização do direito e sustentabilidade: função sócio-solidária da empresa e desenvolvimento. vol. 4. Curitiba: Clássica, 2013.

SILVEIRA, Vladmir Oliveira da; MEZZAROBA, Orides (coordenação); et al. Justiça e [o paradigma da] eficiência. São Paulo: Revista dos Tribunais, 2011.

SILVEIRA, Vladmir Oliveira da; SANCHES, Samyra Naspolini; COUTO, Mônica Bonetti (Organizadores), et al. Direito e Desenvolvimento no Brasil do Século XXI: Desenvolvimento nas Ciências Sociais - o estado das artes, Livro 1. Brasília: CONPEDI, IPEA, 2013.

TAVEIRA, Tôrres, Heleno (coordenador); et al. Direito e Poder: Nas Instituições e nos Valores do Público e do Privado Contemporâneos. 1. ed.Barueri: Manole, 2005.

Trabalho enviado em 27 de novembro de 2017

Aceito em 04 de abril de 2017 